\section{Evaluating Gamma-H2AX Expression as a Biomarker of DNA Damage after X-ray in Angiography Patients}

\author{
Alipoor A. ${ }^{1}$, Fardid R. ${ }^{2,3 *}$, Sharifzadeh S. ${ }^{4}$
}

\begin{abstract}
Objective: Coronary heart disease (CHD) is one of the most common diseases. Coronary angiography $(\mathrm{CAG})$ is an important apparatus used to diagnose and treat this disease. Since angiography is performed through exposure to ionizing radiation, it can cause harmful effects induced by double-stranded breaks in DNA which is potentially life-threatening damage. The aim of the present study is to investigate phosphorylation of Histone H2AX in the location of double-stranded breaks in peripheral blood lymphocytes as an indication of biological effects of radiation on angiography.

Materials and Methods: This method is based on the phosphorylation measurement of Histone (gamma-H2AX or $\gamma$-H2AX) levels on serine 139 after the formation of DNA double-strand break. $5 \mathrm{cc}$ of blood samples from 24 patients undergoing angiography were taken pre- and post-radiation. Blood lymphocytes were extracted, fixed and stained with specific $\gamma$-H2AX antibodies. Finally, the percentage of phosphorylation of Histone $\mathrm{H} 2 \mathrm{AX}$ as an indicator of double-strand break was measured by a cytometry technique.
\end{abstract}

Results: An increase was observed in all patients' percentage of phosphorylated Histone H2AX (double-stranded breaks DNA) after radiation (20.15 \pm 14.18$)$ compared to pre-exposure time $(1.52 \pm 0.34)$. Also, the mean of DNA double-strand break is shown in a linear correlation with DAP.

Discussion: Although induction of DNA double-strand breaks was associated with the radiation dose in patients, the effect of individual factors such as radio-sensitivity and regenerative capacity should not be ignored. In the future, if we are able to measure DNA damage response in every angiography patient, we will use it as a biomarker for the patient dose; this will promote public health.

Conclusion: Using flow cytometers readings done automatically is possible to detect $\gamma-\mathrm{H} 2 \mathrm{AX}$ in the number of blood cells, therefore, the use of this technique could play a significant role in monitoring patients.

\section{Keywords}

X-ray, Angiography, Double-strand Break DNA, y-H2AX, DNA Damage

\section{Introduction}

$\checkmark$ oronary Heart Diseases (CHD) are considered to be among the most prevalent and lethal diseases of today's world. Coronary angiography (CAG) has become an important apparatus in the diagnosis and treatment of CHD. the Widespread use of CAG has raised concerns among physicians and patients about the harmful effects of radiation exposure [1]. The findings of this study will help better understand the risks associated with radiation exposure, so that clinicians
${ }^{1}$ M.Sc. Radiology Department, School of Paramedical Sciences, Shiraz University of Medical

Sciences, Shiraz, Iran

${ }^{2}$ Associate Professor,

Radiology Department,

School of Paramedical

Sciences, Shiraz Univer-

sity of Medical Sciences,

Shiraz, Iran

${ }^{3}$ Ionizing and Non-loniz-

ing Radiation Protection

Research Center (INIR-

PRC), School of Para-

medical Sciences, Shiraz

University of Medical

Sciences, Shiraz, Iran

${ }^{4}$ Diagnostic Laboratory

Sciences and Technol-

ogy Research Center,

School of Paramedical

Sciences, Shiraz Univer-

sity of Medical Sciences,

Shiraz, Iran

*Corresponding author:

R. Fardid

Radiology Department,

School of Paramedical

Sciences, Shiraz Univer-

sity of Medical Sciences,

Shiraz, Iran, P. O. Box:

71335- 1755

E-mail: rfardid@sums.

ac.ir

Received: 29 April 2017

Accepted: 27 May 2017 
and patients can make informed decisions about this method, and also it helps determine whether additional strategies are needed to protect patients against radiation exposure [2]. Ionizing Radiation (IR) can cause damage which is usually related to the radiation dose [3]; this damage can, in turn, lead to DNA damage such as base damage, cross-links, Single-Strand Breaks (SSBs) and Double-Strand Breaks (DSBs) [4].

In comparison with SSBs which leave one strand intact to guide the repair, DSBs demand a more difficult repair process. With regard to ionizing radiation, SSB levels are 20-40 times higher than the levels of DSBs do [5], thus, DSBs signal activation usually leads to celldeath and permanent growth arrest [6].

Clinical signs related to DSB-inducing agents vary greatly among people [7]. Therefore, the same radiation dose could lead to severe complications in one patient. However, there is no trace of them in another patient [5].

Since phosphorylated Histone H2AX proteins (gamma-H2AX or $\gamma-\mathrm{H} 2 \mathrm{AX}$ ) depend on the approximate number of DSBs, it is believed that $\gamma-\mathrm{H} 2 \mathrm{AX}$ is a marker $[8,9]$, thus, this marker is able to determine the number of DSBs by using a suitable antibody [10]. Therefore, if we were able to measure the DNA damage responses in each patient, we could use this signal as a guide for our radiation dose [5]. The aim of this paper is to study the phosphorylation of Histone $\mathrm{H} 2 \mathrm{AX}$ at the site of DSBs in peripheral blood lymphocytes as a marker for the biological effects of radiation on patients undergoing angiography.

\section{Materials and Methods}

An experimental study was carried out in 24 patients. Blood samples were taken before and after 10 minutes angiography in order to evaluate DSBs based on H2AX phosphorylation. Our study exclusion criteria include; the history of Lymphoma or Leukaemia, radiotherapy or chemotherapy during the past six months and X-rays within the past two days.
24 patients were enrolled in this study; 12 men and 12 women (50-65 years old). All 24 patients were under treatment for acute coronary syndrome (ACS).

The patients' DSB responses were monitored by determining the phosphorylated Histone $\mathrm{H} 2 \mathrm{AX}$ in the lymphocytes through flowcytometry technique. Blood samples were collected after taking a written informed consent and poured into separate tubes containing an anticoagulant substance (EDTA). Lymphocytes were separated and then the analysis was done with slight changes to the protocol. $3 \mathrm{ml}$ of blood was diluted in PBS with a 1:1 ratio and added to a sterile Falcon tube containing additional Lymphodex with a ratio of 2:1, then, centrifuged for 20 minutes at $3000 \mathrm{rpm}$.

The lymphocyte layer was then separated and after benign washed three times with PBS and centrifuged for five minutes at $2500 \mathrm{rpm}$. It was diluted in $2 \mathrm{ml}$ PBS, then added to a $2 \mathrm{ml}$ microtube and centrifuged for five minutes at $1200 \mathrm{rpm}$. Ultimately, the lymphocytes were diluted in $1 \mathrm{ml}$ PBS, and after a cell count to measure the percentage of phosphorylated Histone H2AX, the solution was ready to be used by a BD Cytofix/Cytoperm fixation/permeabilization kit.

A total of $1 \times 10^{6} \mathrm{cell} / \mathrm{ml}$ was taken from the sample containing lymphocytes and the rest of the test was performed based on Cytofix/ Cytoperm fixation/permeabilization kit (Cat number: 554714) instructions. The cells were diluted in $250 \mu \mathrm{lBD}$ Cytofix/Cytoperm solution and incubated in the dark at $4^{\circ} \mathrm{C}$ for 20 minutes. Next, they were washed with $250 \mu \mathrm{l}$ Buffer 1x BD perm/wash twice. Afterwards, the cells were diluted in a $500 \mu \mathrm{BD}$ perm/ wash Buffer $1 \mathrm{x}$ solution, and $15 \mu \mathrm{l}$ of antibody Alexa Fluor 488 mouse anti-H2AX (ps139) was added to $3 \times 10^{4} \mathrm{cell} / \mathrm{ml}$. At that point, the solution was incubated in the dark at $4^{\circ} \mathrm{C}$ for 30 minutes and washed with $250 \mu \mathrm{BD}$ perm/ wash Buffer 1x twice. Finally, the cells were diluted in PBS, and the flow cytometric analysis was done while it was using a flow cytom- 
eter model BD (Figure 1A and 1B).

It is worth mentioning that four micro-tubes were used in each test (unstained, isotype, before and after).

\section{Statistical Analysis}

Data were analyzed via SPSS Statistics 16.0. Continuous variables were expressed as means $\pm \mathrm{SD}$. The mean percentages of phosphorylated Histone H2AX before radiation were compared with after it by using Wilcoxon

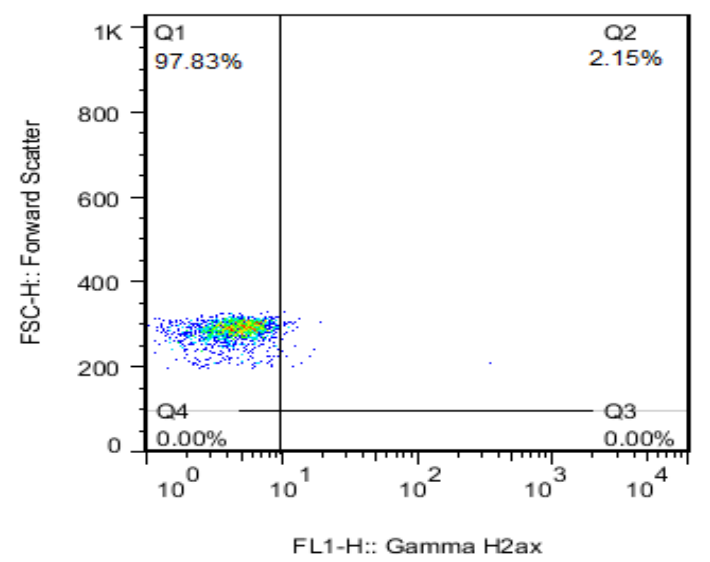

test. The effect of gender was evaluated with Mann-Whitney test. Spearman's correlations (rho, 95\% confidence intervals, $p$ value) were used to evaluate associations among variables. In order to do regression analysis, Stepwise regression was the method of choice.

\section{Ethical Considerations}

All patients signed informed consent and the study was approved by the Ethics Committees in Shiraz University of Medical Sciences.

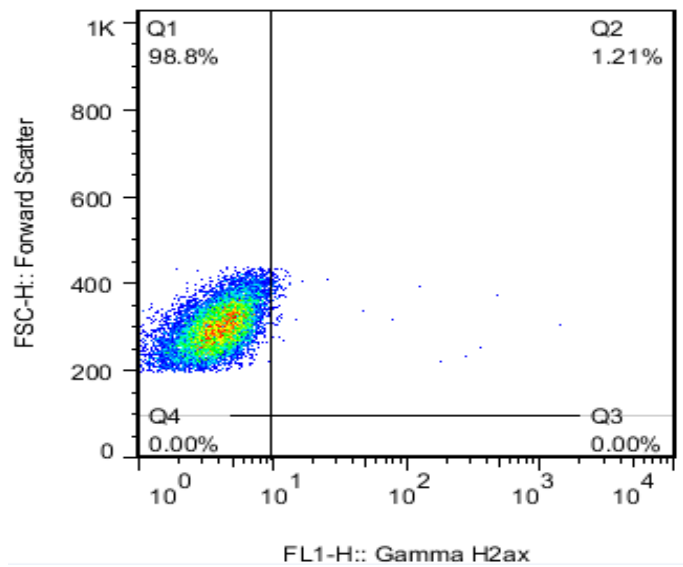

Figure $1 \mathrm{~A}$ : Samples flow cytometry dot plot from two patients before Angiography
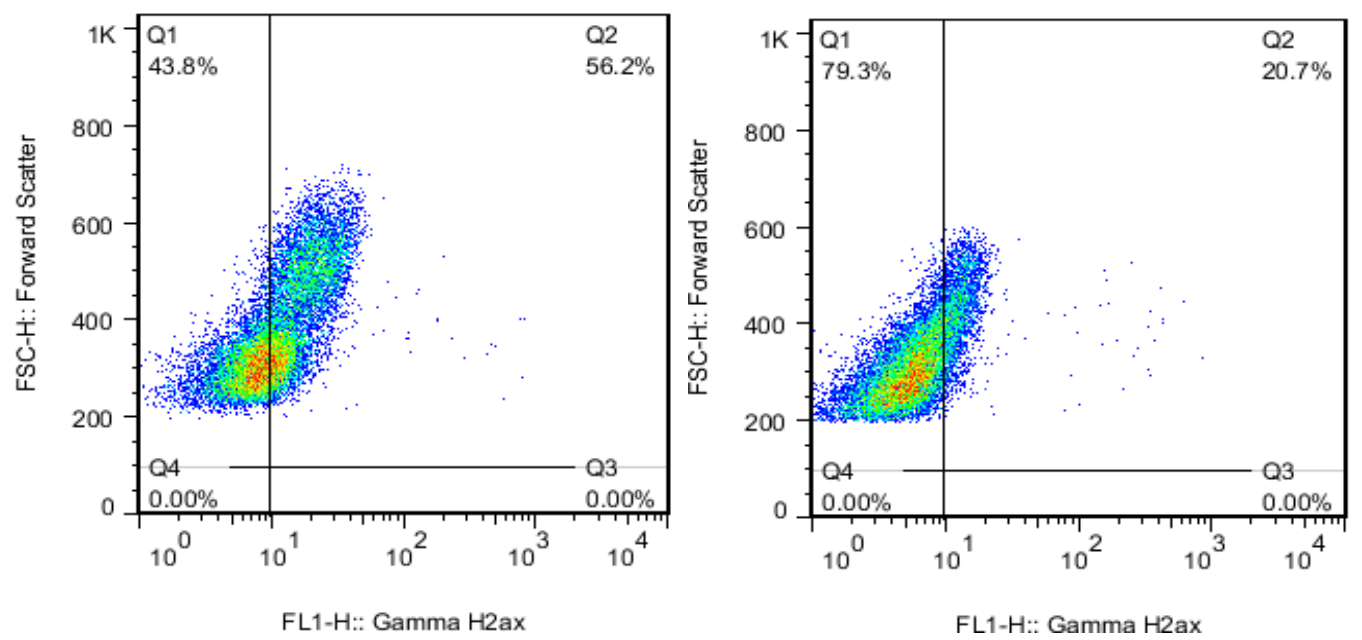

Figure 1 B: Samples flow cytometry dot plot from two patients after Angiography 


\section{Results}

All variables can be seen as mean \pm Std. Deviation (SD) in Table 1.

In order to evaluate the normal distribution of variables, Kolmogorov-Smirnov Test was used. Due to the lack of normality of variables, non-parametric tests were used.

A total of $45 \%$ of patients (11 of 24 ) had a

Table 1: Clinical and angiography parameters of patients.

\begin{tabular}{|c|c|c|c|}
\hline & & Mean & $\begin{array}{c}\text { Std. De- } \\
\text { viation }\end{array}$ \\
\hline \multicolumn{2}{|c|}{ Clinical Parameter } & $58166(50-65)$ & \\
\hline \multicolumn{2}{|c|}{ Age } & $58.100(50-65)$ & \\
\hline \multirow{2}{*}{ Sex } & Male & 12 & 0.090 \\
\hline & Female & 12 & \\
\hline \multicolumn{2}{|c|}{ Scan Parameters } & 1200525 & \\
\hline \multicolumn{2}{|c|}{$\mathrm{DAP}^{*}, \mu \mathrm{Gy} \cdot \mathrm{m}^{2}$} & $4000.0<0$ & $49<0.201$ \\
\hline \multicolumn{2}{|c|}{$\begin{array}{l}\text { blood radiation } \\
\text { dose, } \mathrm{mSv}\end{array}$} & 626.817 & 758.722 \\
\hline \multicolumn{2}{|c|}{ Time, min } & 8.538 & 10.854 \\
\hline \multicolumn{4}{|c|}{${ }^{*} \mathrm{DAP}=$ dose area product } \\
\hline \multicolumn{4}{|c|}{ Patients tested $(n=24)$} \\
\hline
\end{tabular}

$4.6 \%$ increase in phosphorylation. At least, there was one phosphorylation $\mathrm{H} 2 \mathrm{AX}$ after exposure (Figures 2A and 2B).

Wilcoxon test showed that the effect of radiation on the percentage of phosphorylated Histone $\mathrm{H} 2 \mathrm{AX}$ was effective, so that an increase was observed in the percentage of phosphorylated Histone $\mathrm{H} 2 \mathrm{AX}$ after radiation (14.184 \pm $20.151)$ compared to pre-exposure time $(0.3$ $\pm 1.522)$ even when to use very small doses $57 \mathrm{mGy}(534 \mu \mathrm{Gym} 2)$ and (p-value $<0.001$ (The median range(Interquartile) after radiation was $15.90(18.80)$ and 1.53 (0.51) after exposure (Figure3).

Average changes in phosphorylation of any DNA damage marker were lower in patients exposed to $<270 \mathrm{mSv}$ of radiation $7.3 \%$
(4.62\% to $10.34 \%$ ) compared with exposed to $>270 \mathrm{mSv}$ of radiation, $28.21 \%$ (12.37\% to $54.05 \%$ ).

In order to evaluate the effects of gender on the percentage of phosphorylated Histone $\mathrm{H} 2 \mathrm{AX}$ after radiation in patients angiography, Mann-Whitney test results demonstrated no significant difference between the gender of the samples after radiation in the percentage of phosphorylated Histone H2AX (p-val$\mathrm{ue}=0.18$ ).

At least changes were observed in men $21.87 \%$ (mean dose 760.86), while for the women it was $15.384 \%$ (mean dose 492.76 (Figures 3).

The relation among variables was examined by Spearman's correlation test. Spearman's correlation test was used to investigate the effects of different variables (the blood radiation dose, Age, DAP (dose area product) and time) on the percentage of phosphorylated Histone $\mathrm{H} 2 \mathrm{AX}$ after radiation in angiography patients.

According to Table 2, a significant relation was observed among variables (dose, time and DAP) and the percentage of phosphorylated Histone H2AX after radiation $(\mathrm{p}<0.001)$. Accordingly, DNA damage was also associated with radiation dose (Figure 4). However, no significant relation was observed with regard to age variable

\section{Calculation of Correlation Equa- tion}

In our Stepwise regression analysis, the percentage of phosphorylated Histone H2AX after radiation was considered as a response variable (dependent), and the dose, time, DAP,age and percentage of phosphorylated Histone $\mathrm{H} 2 \mathrm{AX}$ are independent variables.

With regard to three variables of DAP, time and Dose, a high correlation was observed in a way that the correlation between the dose and time $(\mathrm{R}=0.975, \mathrm{P}=0.001)$ was significant. This significant correlation was observed between the dose and DAP $(\mathrm{R}=0.998, \mathrm{P}=0.001)$ as well as between time and DAP $(\mathrm{R}=0.969, \mathrm{P}=0.001)$; 


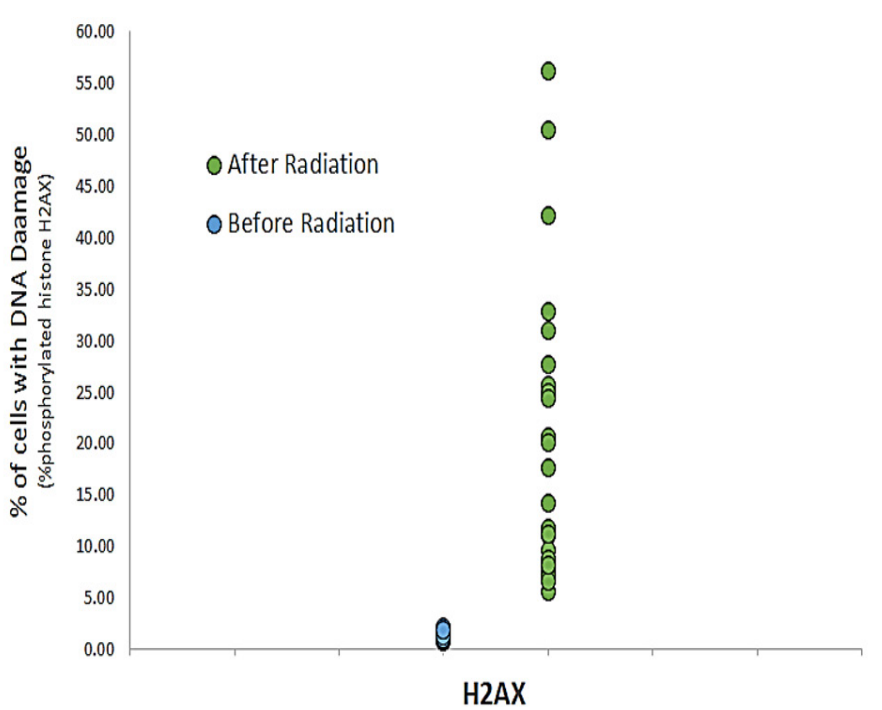

(A)

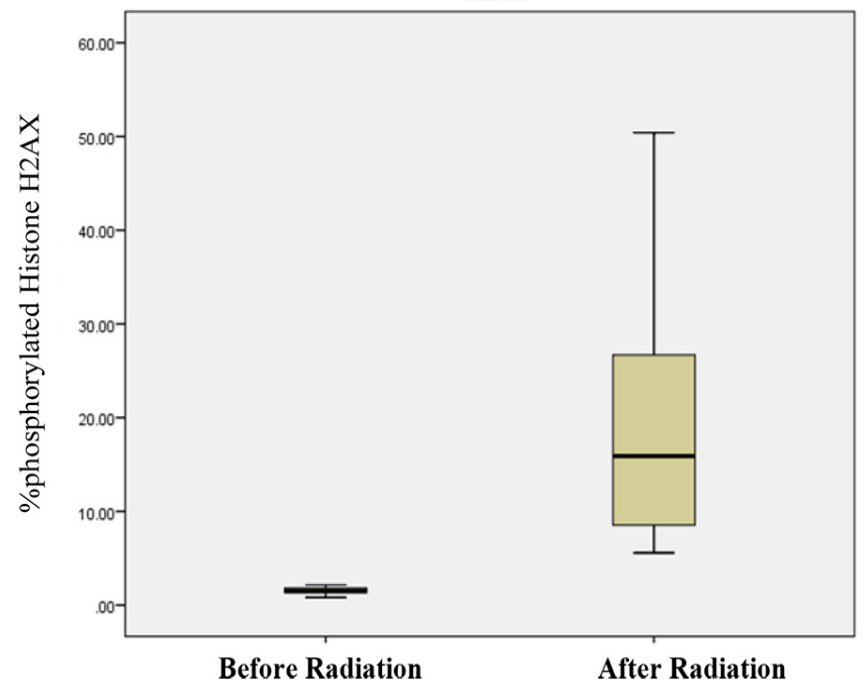

(B)

Figure 2: DNA Damage Detected After Angiography (A) Scatter plot graph of levels of phosphorylated $H 2 A X$, at before and after radiation from CAG. (B) Quantitative assessment of protein biomarkers of DNA damage in patients undergoing CAG

this indicates an extreme collinearity between three variables of DAP, time and dose. These three variables have the same weight in determining the percentage of phosphorylated Histone $\mathrm{H} 2 \mathrm{AX}$ after radiation. Thus, for a better understanding of the correlation between these variables, three regression models have been applied (Table 3).

At first, DAP was considered with sex, age, and percentage of phosphorylated Histone H2AX before radiation variables. In the second the model, the dose was evaluated with sex, age, and the percentage of phosphorylated Histone $\mathrm{H} 2 \mathrm{AX}$ before radiation variables. In the third model, time was investigated with sex, age, and the percentage of phosphorylated Histone $\mathrm{H} 2 \mathrm{AX}$ before radiation variables.

In the first and second models, where only DAP and Dose with the three variables of sex, age, and the percentage of phosphorylated Histone H2AX before radiation were available, only DAP and Dose were significant. Whereas in a third model that time with the three variables of sex, age, and percentage of 


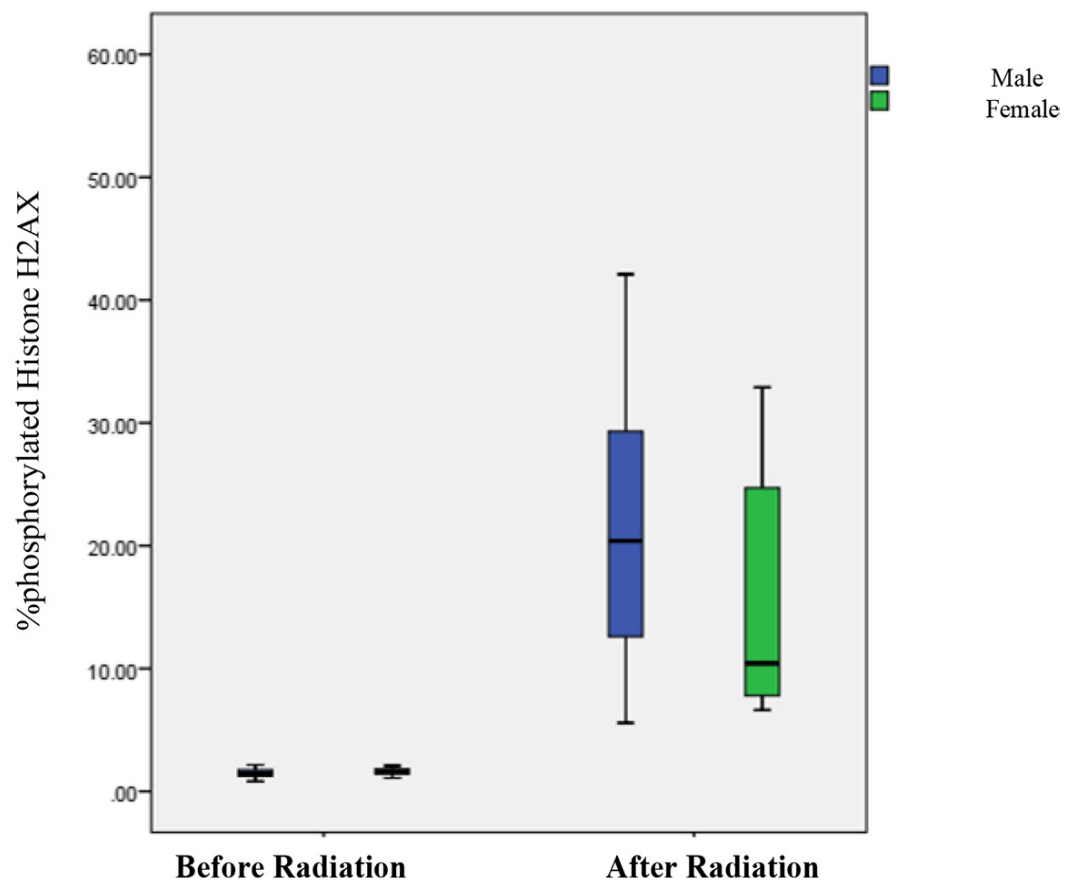

Figure 3: Boxplot graph between the percentage of phosphorylated Histone H2AX before and after radiation with gender

phosphorylated Histone H2AX the before radiation was available, not only time but also sex became significant.

With regards to the average of the percentage of phosphorylated Histone H2AX after radiation in men $(23.33 \pm 14.59)$ and women (16.96 \pm 13.62$)$, which was different? We found that time variable was a better variable to determine the percentage of phosphorylated Histone $\mathrm{H} 2 \mathrm{AX}$ after radiation in comparison with the variables of DAP and Dose. This makes sex variable significant.

\section{Discussion}

After the discovery of X-ray, its adverse effects on biological tissues were manifested [11]. Meanwhile, nowadays it is hard to imagine the medical sciences without the use of Xrays [12].

Following radiation, DNA damage occurs in cells and among damage resulted from ionizing radiation, DSB is the most significant one that can lead to cancer $[8,13]$. Due to its predictability, DSB is considered as a useful mea- sure in researches [5].

After inducing DSB, phosphorylation of a few thousand Histone H2AX molecules would be the first cellular responses [14]. DNA is phosphorylated in a matter of minutes, both caused by SSBs and DSBs [15].

In the repair process of damaged DNA, $\mathrm{H} 2 \mathrm{AX}$ is a key factor that accumulates at the damage site; which is a starting point for other repair mechanisms [14]. After phosphorylation of $\mathrm{H} 2 \mathrm{AX}, \gamma-\mathrm{H} 2 \mathrm{AX}$ can be seen by various techniques [16].

In this study, flow cytometry was used to measure changes in the percentage of phosphorylated Histone H2AX; then, we evaluated the association between changes and the ionizing radiation used in our patients.

Our results revealed a significant increase in the percentage of phosphorylated Histone $\mathrm{H} 2 \mathrm{AX}$ among patients following X-ray exposure.

Using flow cytometry, Macphaila et al. observed the formed $\gamma-\mathrm{H} 2 \mathrm{AX}$ an hour after $20 \mathrm{cGy}$ of radiation. The maximum level of 
Table 2: Correlation-Spearman.

\begin{tabular}{|c|c|c|c|c|c|}
\hline variables & $\begin{array}{l}\text { percentage of phosphorylated } \\
\text { Histone H2AX after radiation }\end{array}$ & Dose & Time & DAP & Age \\
\hline $\begin{array}{l}\text { percentage of phosphorylated } \\
\text { Histone } \mathrm{H} 2 \mathrm{AX} \text { after radiation }\end{array}$ & 1 & - & - & - & - \\
\hline Dose & $0.997^{* *}$ & 1 & - & - & - \\
\hline Time & $0.970^{* *}$ & $0.975^{* *}$ & 1 & - & - \\
\hline DAP & $0.996^{* *}$ & $0.998^{* *}$ & $0.969^{* *}$ & 1 & - \\
\hline Age & -0.044 & -0.052 & -0.016 & -0.049 & 1 \\
\hline
\end{tabular}

$\gamma$-H2AX formation was observed between 1530 minutes after being exposed to radiation, which was consistent with our results [17].

Kuefner et al. evaluated the induction and repair of DSB in peripheral blood lymphocytes among 19 patients (23-88 years of age), using an immunofluorescence microscopy. A number of DSBs (0.03-1.50 per cell) were observed, they observed increases even in small doses (at least 338 micro-Gy*m) [18].

In another study, Kuefner et al. evaluated DSB as a marker for the biological effects of radiation among 31 patients undergoing angi- ography in different body parts by using a fluorescence microscopy. After fluoroscopy, they obtained values of 0.01-1.50 DSBs/cell. There was a linear correlation between $\gamma-\mathrm{H} 2 \mathrm{AX}$ foci levels and DAP (abdomen: $\mathrm{R}^{2}=0.96$; pelvis/ legs: $\mathrm{R}^{2}=0.71$ ) [19].

As it can be seen in Table 2, results from Correlation-Spearman indicated that the induced DSBs reduced based on patients' ages.

Rothkamm and Lobrich measured DSBs in a population of cells using Comet assay; they observed a significant variation in $\gamma-\mathrm{H} 2 \mathrm{AX}$ levels which did not correlate with the mea-

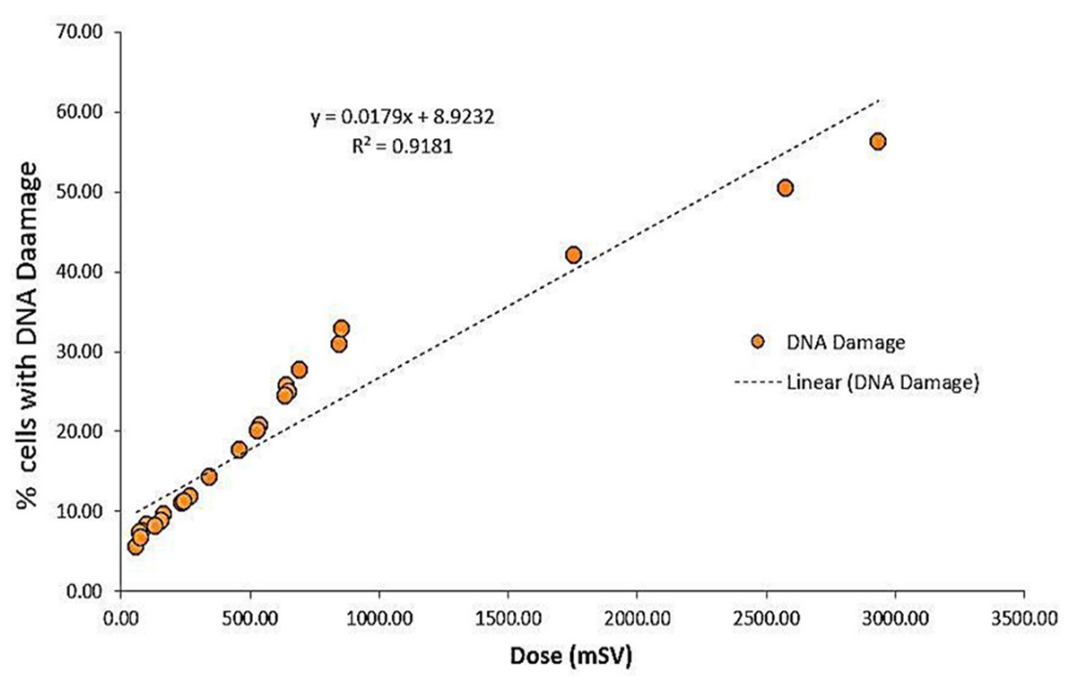

Figure 4: Scatterplot graph of the correlation analysis between DNA damage estimate and radiation dose $(n=24)$. 
Table 3: Correlation Equation

\begin{tabular}{cccc} 
Model & B & Std. Error & P-value \\
\hline DAP & 0.18 & 0.001 & 0.001 \\
\hline Dose & 0.003 & 0.000 & 0.001 \\
\hline Time & $1.22-$ & 0.081 & 0.001 \\
\hline Sex & 4.54 & 1.72 & $<0.05$
\end{tabular}

sured DNA levels and patient's ages. This could have been caused by differences in the number of $\gamma-\mathrm{H} 2 \mathrm{AX}$ formed at a given DNA damage level indicating differences in individuals related to efficiency by which cells convert DSBs to $\gamma-\mathrm{H} 2 \mathrm{AX}$ foci [5].

Vandevoorde et al. examined the blood samples of 51 children undergoing thoracic and abdominal CT scans; they observed a drastic increase in DSBs between the range of 2-10 $\mathrm{mGy}$ doses, their linear regression analysis revealed that the number of induced DSBs per mGy had decreased with age [20]. These results are in line with our findings; however, they cannot explain the age dependency as to its relation with different radio sensitivities or different rates of DSB repair [21].

Since the rate of DSB repair varies among different patients, the rate of damage would vary as well.

Radiation damages are not strictly related to radiation dose and duration but are related to personal factors such as individual repair capacity, radio sensitivity and the use of contrast agents.

Iodinated contrast agents can intensify Xray-induced DNA damages; this could be caused by decreased repair. Another theory is that these effects are caused by the increased photoelectric absorption in Iodine atoms, as well as continuous exposure to nearby lymphocytes [22].

Moreover, another study found a significant correlation between a number of DSBs and blood density levels in the heart and large vessels at the scan site [23].
Due to different blood volumes in different parts of the body, and different numbers of lymphocytes being exposed to radiation, cardiac catheterization causes more damages in comparison to procedures such as abdominal interventions and pelvic angiography, circulatory pathway and the cerebrum $[18,19]$.

Importantly, in this study we recruited patients who had a wide range of radiation dose to determine its effects on DNA damage. Overall, results are in accordance with our hypothesis that higher doses lead to more DNA damage.

Radiation disrupts DNA processes and causes DNA breaks [24]. Our study also revealed DNA damage in lymphocytes of patients undergoing CAG. $\gamma-\mathrm{H} 2 \mathrm{AX}$ is proved to be a sensitive indicator for DSBs induced by ionizing radiation [25]. $\gamma-\mathrm{H} 2 \mathrm{AX}$ shows a significant stability following IR and can be used as a radiosensitive marker [26]. There is a variety of methods in detecting DSBs such as Comet assay, neutral elution and pulse field electrophoresis (2-D gel electrophoresis); however, evaluation via $\gamma-\mathrm{H} 2 \mathrm{AX}$ is a more accurate method in comparison with other methods [4]. This method sensitivity has turned it into a suitable technique for measuring DSB levels.

In this study, we used $\gamma-\mathrm{H} 2 \mathrm{AX}$ to evaluate DNA damage caused during angiographic procedures. Although the use of an immunofluorescence microscopy is currently the most sensitive method for detecting $\gamma-\mathrm{H} 2 \mathrm{AX}$ foci, it is quite difficult to use it in clinical research. On the other hand, flow cytometry can provide us with a simple detection of $\gamma-\mathrm{H} 2 \mathrm{AX}$ in a large number of cells [27].

Numerous reports have indicated a convenient link between $\gamma$-H2AX detected through flow cytometry with the number of DNA breaks, cell deaths and radio sensitivity [17, 28, 29].

\section{Conclusion}

Despite the fact that CAG is a clinical tool 
in the management of cardiovascular patients, physicians and patients' awareness of DNA damage after $\mathrm{CAG}$ is required for dose reduction strategies.

Therefore, based on our study findings we recommend the use of flow cytometry to determine the percentage of phosphorylated Histone H2AX while monitoring patients undergoing angiographic procedures in order to promote health throughout the society.

\section{Acknowledgment}

The present article was extracted from a thesis written by Alieh Alipoor and was financially supported by Shiraz University of Medical Sciences, Shiraz, Iran under Grant No. 11346. The authors wish to thank the Research Consultation Center (RCC) for their invaluable editorial assistance.

\section{Conflict of Interest}

The authors declare no conflict of interest.

\section{References}

1. Douglas $P$, Iskandrian $A E$, Krumholz HM, Gillam L, Hendel $\mathrm{R}$, Jollis $\mathrm{J}$, et al. Achieving quality in cardiovascular imaging: proceedings from the American College of Cardiology-Duke University Medical Center Think Tank on Quality in Cardiovascular Imaging. J Am Coll Cardiol. 2006;48:2141-51. doi: 10.1016/j.jacc.2006.06.076. PubMed PMID: 17113004.

2. Nguyen PK, Lee WH, Li YF, Hong WX, Hu S, Chan $\mathrm{C}$, et al. Assessment of the Radiation Effects of Cardiac CT Angiography Using Protein and Genetic Biomarkers. JACC Cardiovasc Imaging. 2015;8:873-84. doi: 10.1016/j.jcmg.2015.04.016. PubMed PMID: 26210695; PubMed Central PMCID: PMC5019957.

3. Zhang G, Li Y, Wang M, Guo B, Lyu X, Liu JB, et al. Effect of prolonging interval time between coronary angiography and percutaneous coronary intervention on X-ray-induced DNA double-strand breaks in blood lymphocytes. Chin Med J (Engl). 2014;127:2058-62. PubMed PMID: 24890152

4. Kuo LJ, Yang LX. Gamma-H2AX - a novel biomarker for DNA double-strand breaks. In Vivo. 2008;22:305-9. PubMed PMID: 18610740.

5. Ismail IH, Wadhra TI, Hammarsten 0 . An optimized method for detecting gamma-H2AX in blood cells reveals a significant interindividual variation in the gamma-H2AX response among humans. Nucleic Acids Res. 2007;35:e36. doi: 10.1093/nar/ gkl1169. PubMed PMID: 17284459; PubMed Central PMCID: PMC1865071.

6. Tounekti O, Kenani A, Foray N, Orlowski S, Mir LM. The ratio of single- to double-strand DNA breaks and their absolute values determine cell death pathway. $\mathrm{Br} J$ Cancer. 2001;84:1272-9. doi: 10.1054/bjoc.2001.1786. PubMed PMID: 11336481; PubMed Central PMCID: PMC2363894.

7. Burnet NG, Nyman J, Turesson I, Wurm R, Yarnold JR, Peacock JH. The relationship between cellular radiation sensitivity and tissue response may provide the basis for individualising radiotherapy schedules. Radiother Oncol. 1994;33:228-38. PubMed PMID: 7716263.

8. Pilch DR, Sedelnikova OA, Redon C, Celeste A, Nussenzweig A, Bonner WM. Characteristics of gamma-H2AX foci at DNA double-strand breaks sites. Biochem Cell Biol. 2003;81:123-9. doi: 10.1139/003-042. PubMed PMID: 12897845.

9. Sedelnikova OA, Rogakou EP, Panyutin IG, Bonner WM. Quantitative detection of (125)IdU-induced DNA double-strand breaks with gamma-H2AX antibody. Radiat Res. 2002;158:486-92. PubMed PMID: 12236816.

10. Rogakou EP, Boon C, Redon C, Bonner WM. Megabase chromatin domains involved in DNA doublestrand breaks in vivo. J Cell Biol. 1999;146:90516. PubMed PMID: 10477747; PubMed Central PMCID: PMC2169482.

11. Hricak H, Brenner DJ, Adelstein SJ, Frush DP, Hall EJ, Howell RW, et al. Managing radiation use in medical imaging: a multifaceted challenge. Radiology. 2011;258:889-905. doi: 10.1148/radiol.10101157. PubMed PMID: 21163918.

12. Hall EJ, Brenner DJ. Cancer risks from diagnostic radiology. $\mathrm{Br} J$ Radiol. 2008;81:362-78. doi: 10.1259/bjr/01948454. PubMed PMID: 18440940.

13. Rogakou EP, Pilch DR, Orr AH, Ivanova VS, Bonner WM. DNA double-stranded breaks induce histone H2AX phosphorylation on serine 139. J Biol Chem. 1998;273:5858-68. PubMed PMID: 9488723.

14. Kobayashi J. Molecular mechanism of the recruitment of NBS1/hMRE11/hRAD50 complex to DNA double-strand breaks: NBS1 binds to gammaH2AX through FHA/BRCT domain. J Radiat Res. 2004;45:473-8. PubMed PMID: 15635255.

15. Burma S, Chen BP, Murphy M, Kurimasa A, Chen DJ. ATM phosphorylates histone H2AX in response to DNA double-strand breaks. J Biol Chem. 2001;276:42462-7. doi: 10.1074/jbc.C100466200. 
PubMed PMID: 11571274.

16. Chowdhury D, Keogh MC, Ishii H, Peterson CL, Buratowski S, Lieberman J. gamma-H2AX dephosphorylation by protein phosphatase $2 \mathrm{~A}$ facilitates DNA double-strand break repair. Mol Cell. 2005;20:801-9. doi: 10.1016/j.molcel.2005.10.003. PubMed PMID: 16310392.

17. MacPhail SH, Banath JP, Yu TY, Chu EH, Lambur $\mathrm{H}$, Olive PL. Expression of phosphorylated histone H2AX in cultured cell lines following exposure to X-rays. Int J Radiat Biol. 2003;79:351-8. PubMed PMID: 12943243.

18. Kuefner MA, Grudzenski S, Schwab SA, Wiederseiner M, Heckmann M, Bautz W, et al. DNA double-strand breaks and their repair in blood lymphocytes of patients undergoing angiographic procedures. Invest Radiol. 2009;44:440-6. doi: 10.1097/RLI.0b013e3181a654a5. PubMed PMID: 19448553.

19. Kuefner MA, Grudzenski S, Schwab SA, Azoulay S, Heckmann M, Heinrich MC, et al. [X-ray-induced DNA double-strand breaks after angiographic examinations of different anatomic regions]. Rofo. 2009;181:374-80. doi: 10.1055/s-0028-1109063. PubMed PMID: 19280549.

20. Vandevoorde C, Franck C, Bacher K, Breysem L, Smet MH, Ernst $\mathrm{C}$, et al. gamma-H2AX foci as in vivo effect biomarker in children emphasize the importance to minimize $\mathrm{x}$-ray doses in paediatric CT imaging. Eur Radiol. 2015;25:800-11. doi: 10.1007/s00330-014-3463-8. PubMed PMID: 25354556; PubMed Central PMCID: PMC4328121.

21. Kuefner MA, Brand M, Engert C, Schwab SA, Uder M. Radiation Induced DNA Double-Strand Breaks in Radiology. Rofo. 2015;187:872-8. doi: 10.1055/ s-0035-1553209. PubMed PMID: 26333102.

22. Grudzenski S, Kuefner MA, Heckmann MB, Uder M, Lobrich M. Contrast medium-enhanced radiation damage caused by CT examinations. Ra- diology. 2009;253:706-14. doi: 10.1148/radiol.2533090468. PubMed PMID: 19789225.

23. Kuefner MA, Grudzenski S, Hamann J, Achenbach $\mathrm{S}$, Lell M, Anders $\mathrm{K}$, et al. Effect of CT scan protocols on $x$-ray-induced DNA double-strand breaks in blood lymphocytes of patients undergoing coronary CT angiography. Eur Radiol. 2010;20:291724. doi: 10.1007/s00330-010-1873-9. PubMed PMID: 20625737.

24. Hamada N, Schettino G, Kashino G, Vaid M, Suzuki $\mathrm{K}$, Kodama $\mathrm{S}$, et al. Histone H2AX phosphorylation in normal human cells irradiated with focused ultras oft $X$ rays: evidence for chromatin movement during repair. Radiat Res. 2006;166:31-8. doi: 10.1667/RR3577.1. PubMed PMID: 16808616.

25. Chen HT, Bhandoola A, Difilippantonio MJ, Zhu J, Brown MJ, Tai X, et al. Response to RAG-mediated VDJ cleavage by NBS1 and gamma-H2AX. Science. 2000;290:1962-5. PubMed PMID: 11110662; PubMed Central PMCID: PMC4721589.

26. Taneja N, Davis M, Choy JS, Beckett MA, Singh $R$, Kron SJ, et al. Histone H2AX phosphorylation as a predictor of radiosensitivity and target for radiotherapy. J Biol Chem. 2004;279:2273-80. doi: 10.1074/jbc.M310030200. PubMed PMID: 14561744.

27. Olive PL. Detection of DNA damage in individual cells by analysis of histone H2AX phosphorylation. Methods Cell Biol. 2004;75:355-73. PubMed PMID: 15603433.

28. Olive PL, Banath JP. Phosphorylation of histone $\mathrm{H} 2 \mathrm{AX}$ as a measure of radiosensitivity. Int $\mathrm{J}$ Radiat Oncol Biol Phys. 2004;58:331-5. PubMed PMID: 14751500.

29. Banath JP, Olive PL. Expression of phosphorylated histone $\mathrm{H} 2 \mathrm{AX}$ as a surrogate of cell killing by drugs that create DNA double-strand breaks. Cancer Res. 2003;63:4347-50. PubMed PMID: 12907603. 